\title{
Music Therapy for Anxiety Level and Quality of Life of Patients Infected by COVID-19
}

\author{
Siti Nur Hasina*(D), Sulistyorini Sulistyorini(D), Fauziyatun Nisa, Raden Afiyah (D) \\ Faculty of Nursing and Midwifery, Universitas Nahdlatul Ulama Surabaya, Surabaya, East Java, Indonesia
}

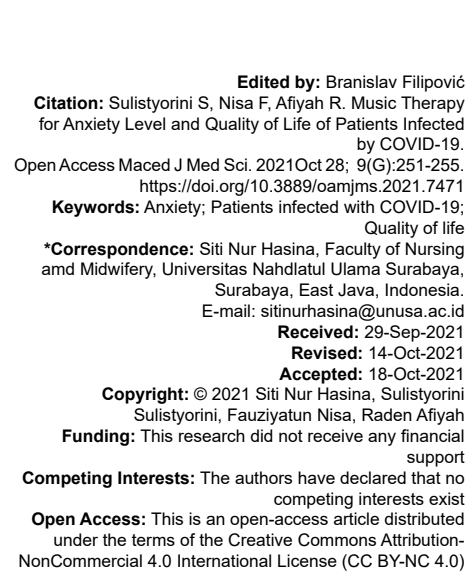

\section{Introduction}

The COVID-19 outbreak has changed the order of life in all fields and not only in Indonesia but also throughout the world [1]. Indonesia is a country that was confirmed to be infected with the coronavirus in early 2020. At that time, Indonesia was not ready to face the situation so that the rapid reaction of socialization as preventive efforts has not been realized by the Indonesian government, so that the coronavirus outbreak affects all Indonesian people badly [2]. The WHO and public health authorities around the world make efforts in resisting and preventing the COVID-19 outbreak, but this outbreak has a negative impact on mental health such as stress and anxiety on the world's population [3], [4].

The Indonesian government recorded that on December 1, 2020, there were 543.975 with 72.015 active cases and 17.081 death cases [5]. In Rumah Sakit Islam Surabaya, the number of cases recorded in the past 3 months was 156 cases with 32 death cases in August, 175 cases with 34 death cases in September, and 148 cases with 22 death cases in October.
COVID-19 is a frightening disease that causes anxiety in all levels of society because COVID-19 attacks the respiratory system and causes death [6]. This pandemic is so frightening that it causes stress in the form of restless, fear, and anxiety which have a direct impact on a person's quality of life [7], [8]. Anxiety is a feeling of worry, anxious, restlessness, uncomfortable, and pleasant [6]. Several studies suggested that anxiety is generally caused by genetic and non-genetic factors. Stress is a non-generic factor which triggers the anxiety in patients [9].

Anxiety can cause shortness of breath worse and aggressive behavior resulting in patient non-compliance. There is a new term in the psychiatric literature referring to excessive fear of being infected by COVID-19, namely, Coronaphobia [10]. There are several types of anxiety, including general anxiety, panic disorder anxiety, social anxiety, and obsessive anxiety. COVID-19 pandemic can cause anxiety disorders in public which is characterized by sleep disorders which are very risky for committing suicide, anxiety, shortness of breath, tense muscles, panic buying, and obsessive-compulsive disorder [11]

Anxiety disorders arise because of a threatening situation that is a normal reaction to stress. People with 
anxiety disorders tend to experience panic attacks and fear as well. A person is certain that something terrifying will happen during a panic attack. This feeling is usually accompanied by certain symptoms. These symptoms usually occur as a result of the activation of the sympathetic branch of the autonomic nervous system and are reactions that others experience when they are very scared. During a severe panic attack, it is usually because someone is afraid of death [7]. In addition, according to Brown and Roose (2011), anxiety has an impact on decreasing the quality of life of sufferers of the disease, concluding that the impact of anxiety and depression on individuals can be seen from the aspect of quality of life in all age ranges [12].

The interventions on anxiety are pharmacological and non-pharmacological. Pharmacological intervention can reduce anxiety and depression. However, it has side effects and causes possibility of recurrent symptoms when the dose is reduced [13]. Meanwhile, the nonpharmacological intervention in overcoming anxiety and improving their quality of life of patients infected with COVID-19 is music therapy [14], [15]. That angklung music can improve the quality of life of elderly women in the physical, psychological, social relations, and environmental domains [14]. Anxiety that occurs during the COVID-19 pandemic can be overcome with music therapy. Music therapy is a therapy that does not have a detrimental effect on adolescents and can reduce anxiety levels by increasing endorphins. The intervention group with music therapy got a mean value before the intervention was 12.5 (moderate anxiety) and after being given an intervention in the form of music therapy the mean decreased to 5.5 (normal anxiety) and $p=0.000$ [15].

Music is a universal language for the world's population which is very effective to be used in intervention because patients can choose and doing it independently [16]. Music therapy has been widely used as a therapy in overcoming anxiety. Jasemi et al. (2016) research confirmed that the use of musk therapy can reduce depression and anxiety in cancer patients and is recommended as nursing care in dealing with depression and anxiety. The purpose of this study was to analyze the effect of music therapy on anxiety and the quality of life of patients infected by COVID-19 [17].

\section{Methods}

The type of this research was experimental quantitative research using a randomized controlled trial research design. This research was conducted for 3 months from November 2020 to January 2021 at Rumah Sakit Islam Surabaya Ahmad Yani. The samples in this study were patients, who were confirmed positive for COVID-19 aged 18-50 years old, were willing to be participants in the study, liked music, as well as could read and write. The sampling used technique in this study was simple random sampling, while the data analysis was performed using $t$ paired test and $t$ independent test. The researcher performed the statistical data analysis with SPSS.

This study was divided into two groups; those are the intervention group of 51 respondents who received intervention in the form of music therapy and 51 respondents in the control group who were only given regular intervention. Each intervention group received an intervention in the form of music therapy for $20 \mathrm{~min}$ for 6 days during the isolation period in the hospital. The provision of music therapy is carried out with the media of mp4 players in which the favorite and newest songs have been set with the genres of religious-themed music, dangdut, pop, and classical music. Music was selected according to the participant's favorites. The songs that are set do not contain songs with sad music. So for 20 min participants are free to choose music that has been prepared by the researcher in the media mp4 players.

Data collection tool or anxiety questionnaire used Hamilton Anxiety Rating Scale (HARS) with a reliability of 0.893 . HARS score indicator $<14=$ none, score 14-20 experienced mild anxiety, score 21-27 experienced moderate anxiety, score 28-41 experienced severe anxiety, and score 42-56 experienced very severe anxiety. The measuring tool for quality of life used WHO QOL BREF Indonesian translation which has a validity test value $0.372-0.883$ and a reliability value of $0.662-0.856$ [14]. Anxiety levels and quality of life were measured on the $1^{\text {st }}$ day the patient entered the isolation room for pre-test assessment and after 6 days the anxiety level and quality of life were measured again for post-test assessment.

This study was conducted using an online method where participants previously agreed to an informed consent form with ethical considerations of anonymity, beneficence, and maleficence. This research has been ethically tested with an ethical code number 006/EC/KEPK-STIKES_Kendal/X/2020.

\section{Results}

The results of this research are as follows:

Table 1 shows that the frequency distribution according to age shows that the majority $(51 \%)$ of respondents in the intervention group were at the age of $31-40$ years old, while almost half $(47 \%)$ of the control group respondents were at the age of 31-40 years old. According to the gender, it was found that most of the respondents $(70.6 \%)$ in the intervention group were male, while most of the respondents in the control group $(62.7 \%)$ were male. 
Table 1: Characteristics of respondents by age and gender in the intervention and control groups $(n=102)$

\begin{tabular}{|c|c|c|c|c|c|c|}
\hline \multirow{3}{*}{$\begin{array}{l}\text { Characteristics } \\
\text { of respondents }\end{array}$} & \multicolumn{4}{|c|}{ Groups } & \multirow{2}{*}{\multicolumn{2}{|c|}{ Total }} \\
\hline & \multicolumn{2}{|c|}{ Group 1 (Intervention) $(\mathrm{n}=51)$} & \multicolumn{2}{|c|}{ Group 2 (Control) $(\mathrm{n}=51)$} & & \\
\hline & $\bar{F}$ & $\%$ & $\bar{F}$ & $\%$ & $F$ & $\%$ \\
\hline \multicolumn{7}{|l|}{ Ages } \\
\hline $18-30$ year & 10 & 19.6 & 11 & 21.6 & 21 & 20.6 \\
\hline $31-40$ year & 26 & 51.0 & 24 & 47.0 & 50 & 49.0 \\
\hline $41-50$ year & 15 & 29.4 & 16 & 31.4 & 31 & 30.4 \\
\hline \multicolumn{7}{|l|}{ Gender } \\
\hline Male & 36 & 70.6 & 32 & 62.7 & 68 & 66.7 \\
\hline Female & 15 & 29.4 & 19 & 37.3 & 34 & 33.3 \\
\hline
\end{tabular}

Table 2 shows that the results of the normality test of the anxiety and the quality of life variables pre-test and post-test in the intervention group and the control group using the Shapiro-Wilk test obtained $p$ value $>0.05$, which means that the data distribution was normal so that data analysis can be continued using the statistical test-t.

Table 2: Normality test of anxiety and quality of life in the intervention and control groups before and after obtaining therapy intervention

\begin{tabular}{lll}
\hline Groups & Uric acid levels and quality of life & $\rho^{*}$ \\
\hline Intervention & Pre-test anxiety & 0.192 \\
& Post-test anxiety & 0.262 \\
& Quality of life pre-test & 0.147 \\
& Post-test quality of life & 0.132 \\
Control & Pre-test anxiety & 0.115 \\
& Post-test anxiety & 0.103 \\
& Pre-test quality of life & 0.147 \\
& Post-test quality of life & 0.061 \\
\hline${ }^{*}>>0.05$ Based on Shapiro-Wilk test. &
\end{tabular}

Table 3 shows that the statistical test of $t$ independent before giving the music therapy obtained mean value of 31.8 (severe anxiety) on intervention group and 28.7 (severe anxiety) on control group with significance value of 0.265 which means that there was no difference in anxiety both in intervention and control groups before giving the music therapy. Meanwhile, after the music therapy was provided, the mean value of the intervention group was 18.7 (mild anxiety) while the mean value of control group was 33.6 (severe anxiety) with significance value of 0.000 , which means that there was difference on anxiety means of both intervention and control groups.

Table 3: Distribution of anxiety variable values (pre- and post-test) in the intervention group and the control group ( $n=51$ and $n=51$ )

\begin{tabular}{lllll}
\hline Groups & Mean & St. dev & T & Significant \\
\hline Intervention control & & & & \\
$\quad$ Pre & 31.8 & 8.340 & -4.802 & 0.265 \\
$\quad$ Pre & 28.7 & 7.818 & & \\
Intervention control & 18.7 & 10.576 & -4.802 & 0.000 \\
$\quad$ Post & 33.6 & 7.822 & & \\
$\quad$ Post & &
\end{tabular}

Table 4 presents the results of the independent $t$ statistical test showing that the mean value of the intervention group before obtaining music therapy was 39.2 (poor quality of life), while the control group obtained mean value of 39.3 (poor quality of life) with a significance value of 0.973 which means no differences were found on the mean value of the life quality of both groups before obtaining music therapy. After music therapy was provided, it was found that the mean value of the intervention group was 81.6 (very good quality of life), while the control group obtained mean value of 36.7 (poor quality of life) with a significance value of 0.000 . It means that there was a difference on the mean value of life quality both in the intervention and the control groups.

Table 4: The distribution of value on life quality variable (preand post-test) on intervention and control groups ( $n=51$ and $\mathbf{n}=\mathbf{5 1}$ )

\begin{tabular}{lllll}
\hline Groups & Mean & St. dev & $\mathrm{t}$ & Significance \\
\hline Intervention control & & & & \\
$\quad$ Pre & 39.2 & 4.586 & 0.034 & 0.973 \\
$\quad$ Pre & 39.3 & 5.156 & & \\
Intervention control & & & & \\
$\quad$ Post & 81.6 & 9.324 & 19.11 & 0.000 \\
$\quad$ Post & 36.7 & 3.544 & & \\
\hline
\end{tabular}

\section{Discussion}

The coronavirus or COVID-19 can infect anyone, but some groups have a high risk of being exposed to the virus [18]. In this study, it was found that most of the COVID-19 patients were male. According to patient data in Wuhan, it showed that many men were infected with COVID-19 and even the Chinese Center for Disease Control and Prevention stated that men infected with COVID-19 have a risk of dying twice as high as women who are infected. This finding was also proven in Italy where the death rate in men was much higher than in women [19]. Nearly half of the age in this study, both the intervention group and the control group, was $30-40$ years old. Patients confirmed to be positive for COVID-19 were not only the elderly but the $40-49$ age groups who accounted for a mortality rate by $12.5 \%$ and those aged under 40 years accounted for $6.25 \%$ of deaths [20].

The emergence of COVID-19 in 2019 has attracted global attention so that the $\mathrm{WHO}$ has declared COVID-19 as public health emergency in the world [21]. COVID-19 has caused confusion, changed the living conditions of people who usually live socially, emergence of travel restrictions, fear of disease transmission, closure of schools, colleges, businesses, and a chronic impact for all, namely, anxiety [22]. Patients who are hospitalized with positive COVID-19 have anxiety due to fear of death [20]. In addition, the large number of false reports about COVID-19 and no family support while being treated at the hospital makes patients even more anxious.

The mean value of respondents' anxiety in intervention group before obtaining music therapy was 31.8 which means they experienced severe anxiety, while in the control group was 28.7 which also means severe anxiety. After being treated in the intervention group, the mean value of the anxiety decreased to 18.7 which means that the respondents experienced mild anxiety, while the respondents in the control group obtained 33.6 which means experiencing severe anxiety. This study is in line with the research performed 
by Wu et al., (2017) that music therapy can significantly reduce anxiety, lower heart rate, and blood pressure over time [23].

Music therapy is used to reduce stress because music has a positive effect on physiological (e.g., heart rate, blood pressure, and hormonal levels) and experiences of psychological stress (e.g., restlessness, anxiety, and panic) [24]. Listening to music and making music are closely related to positive outcomes and are present in the domain of health and well-being [23], [24]. The anxiety felt by patients with COVID-19 was closely related to the patient's quality of life. In this study, it was found that the quality of life of the respondents in the intervention group and control group on average was poor. After music therapy was provided, it was found that the intervention group experienced an increase in the average quality of life, namely, 81.6 (very good quality of life) and the control group experienced an average increase of 36.7 (poor quality of life).

Music therapy affects the emotional form of stress that causes feelings of anxiety, worry, fear, and panic [27], [28]. Music can modulate activity in the brain that is considered to influence emotional processes. Recent neuroimaging studies showed that music and emotions have a positive effect on the amygdala which is part of the limbic system. The limbic system has an important role as a regulator of emotional processes by releasing endorphins. This neurotransmitter plays an important role in enhancing a sense of well-being [26], [29], [30], [31], [32], [33].

\section{Conclusions}

Music therapy can reduce anxiety and improve the patient's quality of life of the patients who were hospitalized due to COVID-19. This research can be used as a reference in providing non-pharmacological therapy to patients infected with COVID-19 who experience mild anxiety to very severe anxiety so that it has an impact on the quality of life of patients who are in hospital or self-isolated at home. Music therapy is very easy to do independently, efficiently, and effectively in reducing anxiety and improving the quality of life of patients infected by COVID-19.

\section{Acknowledgments}

The author would like to thank the Rumah Sakit Islam Surabaya Ahmad Yani, all the COVID-19 patients involved in this study and we especially say thank you very much to the Universitas Nahdlatul Ulama Surabaya, which is very supportive for this research.

\section{References}

1. Darwis P. COVID-19 is changing our lives. Indones J Surg 2020;48(1):1-2. https://doi.org/10.46800/jibi-ikabi.v48i1.52

2. Harisah H. Policy on intensive administration of Corona COVID19 virus medical personnel; maslahah approach. J Sosial Budaya Syar. 2020;7(6):519-28. https://doi.org/10.15408/sjsbs. v7i6.15320

3. World Health Organization. Mental Health and Psychosocia Considerations during the COVID-19 Outbreak. Geneva: World Health Organization; 2020. Available from: https:// www.who.int/docs/default-source/coronaviruse/mental-healthconsiderations.pdf [Last accessed on 2021 Jan 18].

4. Schäfer SK, Sopp MR, Schanz CG, Staginnus M, Göritz AS, Michael T. Impact of COVID-19 on public mental health and the buffering effect of a sense of coherence. Psychother Psychosom. 2020;89(6):386-92. https://doi.org/10.1159/000510752 PMid:32810855

5. Kompas. UPDATE 1 Desember: Ada 72.015 Kasus Aktif COVID19 di Indonesia; 2020. Available from: https://www.nasional. kompas.com/read/2020/12/01/16315681/update-1-desemberada-72015-kasus-aktif-covid-19-di-indonesia [Last accessed on 2021 Jan 17].

6. Suryaatmaja DJ, Wulandari IS. The relationship of anxiety levels to adolescent attitudes due to the COVID-19 pandemic. Manuju. 2020;2(4):820-9.

7. Jarnawi J. Mengelola cemas di tengah pandemik corona. J At-Taujih Bimbingan Konseling Islam. 2020;3(1):1-14 Available from: http://www.jurnal.ar-raniry.ac.id/index.php/taujih [Last accessed on 2021 Jan 17]. https://doi.org/10.22373/taujih. v3i1.7216

8. Suryani A. Hubungan Antara Tingkat Kecemasan Dengan Kualitas Hidup Lanjut Usia Di Panti Wredha Dharma Bhakti Pajang Surakarta, Skripsi. Indonesia: Universitas Muhammadiyah; 2016.

9. Wulandari P, Hidayat R. General anxiety disorder-related Coronavirus disease-19 outbreak in Indonesia: A case report. Open Access Maced J Med Sci. 2020;8(T1):36-8. https://doi. org/10.3889/oamjms.2020.4762

10. Asmundson GJ, Taylor S. Coronaphobia: Fear and the 2019nCoV outbreak. J Anxiety Disord. 2020;70:102196. https://doi. org/10.1016/j.janxdis.2020.102196 PMid:32078967

11. Sari I. Analysis of the impact of the COVID-19 pandemic on public anxiety: Literature review. 2020;12(1):69-76. https://doi. org/10.35907/bgjk.v12i1.161

12. Brown PJ, Roose SP. Age and anxiety and depressive symptoms: The effect on domains of quality of life. Int J Geriatr Psychiatry. 2011;26(12):1260-6. https://doi.org/10.1002/gps.2675 PMid:21351152

13. Stark $\mathrm{D}$, House $\mathrm{A}$. Anxiety in cancer patients. $\mathrm{Br} \mathrm{J}$ Cancer 2000;83(10):1261-7. https://doi.org/10.1054/bjoc.2000.1405 PMid:11044347

14. Komariah L. Pengaruh musik angklung terhadap kualitas hidup wanita lanjut usia. J Pendidikan Keperawatan Indones. 2016;2(1):1-6. Available from: http://www.ejournal.upi.edu/ index.php/jpki [Last accessed on 2021 Jan 17]. https://doi. org/10.17509/jpki.v2i1.2847

15. Hasina S, Khafid M. Effect of sleep hygiene and ergonomic exercise based on spiritual care on uric acid levels and quality of life for gouty arthritis sufferers. 2020;12(2):203-16. https://doi. org/10.32583/keperawatan.v12i2.753

16. Pramita BP, Haurawan F, The effect of music therapy on reducing anxiety levels of patients with preoperative caesarean section at the mother and child hospital, Pusura Tegalsari, Surabaya. J 
Sains Psikologi. 2019;5(2):6-9.

17. Jasemi M, Aazami S, Zabihi RE. The effects of music therapy on anxiety and depression of cancer patients. Indian J Palliat Care. 2016;22(4):455-8. https://doi.org/10.4103/0973-1075.191823 PMid:27803568

18. Rothan HA, Byrareddy SN. The epidemiology and pathogenesis of Coronavirus disease (COVID-19) outbreak. J Autoimmun. 2020;109:102433. https://doi.org/10.1016/j.jaut.2020.102433 PMid:32113704

19. Siagian TH. Looking for groups at high risk of being infected with the corona virus with discourse network analysis. J Kebijakan Kesehatan Indones. 2020;9(2):1-9. https://doi.org/10.22146/ jkki.55475

20. Ilpaj SM, Nurwati N. Analisis pengaruh tingkat kematian akibat COVID-19 terhadap kesehatan mental masyarakat di Indonesia. Focus J Pekerjaan Sosial. 2020;3(1):16-28. Available from: http://www.jurnal.unpad.ac.id/focus/article/view/28123 [Last accessed on 2021 Jan 20].

21. Dong $\mathrm{Y}, \mathrm{Mo} \mathrm{X}, \mathrm{Hu} \mathrm{Y}, \mathrm{Qi} \mathrm{X}$, Jiang $\mathrm{F}$, Jiang $\mathrm{Z}$, Tong $\mathrm{S}$. et al. Epidemiology of COVID-19 among children in China. Pediatrics. 2020;145(6):e20200702. https://doi.org/10.1542/peds.2020-0702 PMid:32179660

22. Fardin MA. COVID-19 and anxiety: A review of psychological impacts of infectious disease outbreaks. Arch Clin Infect Dis. 2020;15:e102779. https://doi.org/10.5812/archcid.102779

23. Wu PY, Huang ML, Lee WP, Wang C, Shih WM. Effects of music listening on anxiety and physiological responses in patients undergoing awake craniotomy. Complement Ther Med. 2017;32:56-60. https://doi.org/10.1016/j.ctim.2017.03.007 PMid:28619305

24. de Witte M, Spruit A, van Hooren S, Moonen X, Stams GJ. Effects of music interventions on stress-related outcomes: A systematic review and two meta-analyses. Health Psychol Rev. 2020;14(2):294-324. https://doi.org/10.1080/17437199.20

\subsection{7 \\ PMid:31167611}

25. Koelsch S. Brain and Music. Oxford: John Wiley; 2012.

26. Koelsch S. Music-evoked emotions: Principles, brain correlates, and implications for therapy. Ann NY Acad Sci. 2015;1337:193-201. https://doi.org/10.1111/nyas.12684 PMid:25773635

27. Akin A, Iskender M. Internet addiction and depression, anxiety and stress. Int Online J Educ Sci. 2011;3:138-48. Available from: http://www.mts.iojes.net [Last accessed on 2021 Jan 20].

28. Pittman S, Kridli S. Music intervention and preoperational anxiety: An integrative review. Int Nurs Rev. 2011;58(2):157-63. https://doi.org/10.1111/j.1466-7657.2011.00888.x PMid:21554287

29. Hodges DA. Psychophysiological measures. In: Juslin PN, Sloboda J, editors. Handbook of Music and Emotion. Oxford: Oxford University Press; 2011. p. 279-311.

30. Koelsch S, Siebel W, Fritz T. Functional neuroimaging. In: Juslin PN, Sloboda J, editors. Handbook of Music and Emotion. Oxford: Oxford University Press; 2011. p. 313-45.

31. Uhlig S, Jaschke A, Scherder E. Effects of music on emotion regulation: A systematic literature review. In: Luck G, Brabant O, editors. The $3^{\text {rd }}$ International Conference on Music and Emotion, Jyväskylä; 2013. Available from: https://www.jyx.jyu.fi/ handle/123456789/41628 [Last accessed on 2021 Jan 20].

32. Zatorre RJ. Musical pleasure and reward: Mechanisms and dysfunction. Ann NY Acad Sci. 2015;1337:202-11. https://doi. org/10.1111/nyas.12677 PMid:25773636

33. Sulistyorini S, Hasina SN, Millah I, Faishol F. Music therapy to reducing adolescent anxiety during the COVID-19 pandemic. J IImu Keperawatan Jiwa. 2021;4(2):289-96. Available from: https://www.journal.ppnijateng.org/index.php/jikj/article/ view/944 [Last accessed on 2021 Jan 20]. 